\title{
Gastric Foreign Body Case in a Dolphin: Endoscopic Approach
}

\author{
Turan CİVELEK ${ }^{1, *}$, Ali ERFİDAN ${ }^{2}$, Durmuş Fatih BAŞER ${ }^{3}$, Olgun ASLAN ${ }^{4}$, Hidayet ŞİMŞEK ${ }^{5}$ \\ 1,2,3 Afyon Kocatepe University, Faculty of Veterinary Medicine, Department of Internal Medicine, Animal Hospital, ANS Campus, \\ Afyonkarabisar/TURKEY \\ ${ }^{4} Y$ eni Maballe District, Dortyol Street, No: 16/G, Kemer, Antalya/TURKEY \\ ${ }^{5}$ Hasvet, Mehmetcile District, 1242 Street, No:3B/2 Muratpaşa, Antalya/TURKEY
}

\section{S U M M A R Y}

In this report gastric foreign body case in a dolphin were described. The case material presented was formed by an adult bottlenose dolphin sheltered in a private dolphin park in Antalya province, Turkey. We intervened after the veterinary who is in charge of the dolphinarium contacted us with a suspicion of "gastric foreign body". Endoscopic procedure was performed for diagnostic and therapeutic purposes, and a diving mask firmly settled in the distal of the forestomach was diagnosed. Although the foreign body was repeatedly grasped using grasping forceps, it disengaged from the forceps due to the large and heavy structure and slippery surfaces and the removal was unsuccessful in performed gastroscopic procedure. However, at present the best method to use in the diagnosis of foreign bodies and removal of these swallowed objects in the appropriate structure in dolphins is gastroscopy.

Key Words:Delphinidae, Gastroscopy, Marine mammals, Turkey

\section{Bir Yunusta Gastrik Yabancı Cisim Olgusu: Endoskopik Yaklaşım}

\begin{abstract}
ÖZET
Bu raporda bir yunusta gastrik yabancı cisim olgusu tanımlandı. Olgu materyalini Antalya, Türkiye’ deki özel bir yunus parkında barındırılan yetişkin şişeburun ırkı bir yunus oluşturdu. Yunus parkı sorumlu veteriner hekiminin "gastrik yabanc1 cisim" şüphesi ile bizimle temasa geçmesi sonrası tarafımızca olguya müdahale edilmiştir. Olguda tanı ve uzaklaştırma amaçlı endoskopik prosedür uygulandı ve distal ön midede sıkıca yerleşmiş bir dalış maskesi teşhis edildi. Gerçekleştirilen gastroskopik prosedür dahilinde yabancı cisim defalarca yakalanmasına rağmen, geniş ve ağır yapısı ve kaygan yüzeyi nedeniyle, forceps ağzından kurtuldu ve uzaklaștırma bașarısız oldu. Bununla birlikte, hali hazırda, yunuslarda yutulmuș yabancı cisimlerin tanısında ve aynı zamanda uygun yapıda olanların uzaklaştırılmasında kullanılabilecek en iyi yöntem gastroskopidir.
\end{abstract}

Anahtar Kelimeler: :Deniz memelileri, Gastroskopi, Türkiye, Yunusgiller 


\section{INTRODUCTION}

The habit of foreign body swallowing is an important problem for captive marine mammals (Kyung-Yeon et al 2013). The marine mammals that are educated for shows and have to maintain their life under human control often develop the bad habit of swallowing foreign bodies that fall into the pool. The basic solution is to keep foreign bodies away from these animals (Stoskopf 1998). If the event occurs, diagnosis and removal of swallowed foreign bodies is required and recommended.

The number of reports have been published about the foreign body cases in dolphins including diagnostic procedures and removal techniques are very limited (Web of Sci.). Therefore, although unsuccessful foreign body removal process, the presented case is important because it is the first case reported in Turkey and it is first case related to the ingestion of a diving mask and it contains some new approaches not defined before in the literature about gastroscopy in dolphins. In this presented report we aim to relate our experience on endoscopic attempt in gastric foreign body case in a dolphin to other clinicians and researchers who are involved with endoscopy in marine mammals.

\section{CASE HISTORY}

\section{Anamnesis and Clinical Examination}

The case material presented was formed by an adult (18 yo) male bottlenose dolphin (Tursiops truncatus gilli) weighing nearly $250 \mathrm{~kg}$ with a length slightly over 2.95 meters. It was reported in the anamnesis information that a professional diving mask was likely swallowed by the dolphin several weeks ago. In our clinical examination, no clinical findings such as abnormal activity, uneasiness, lethargy, loss of appetite, weight loss, regurgitation, vomiting, etc. were identified.

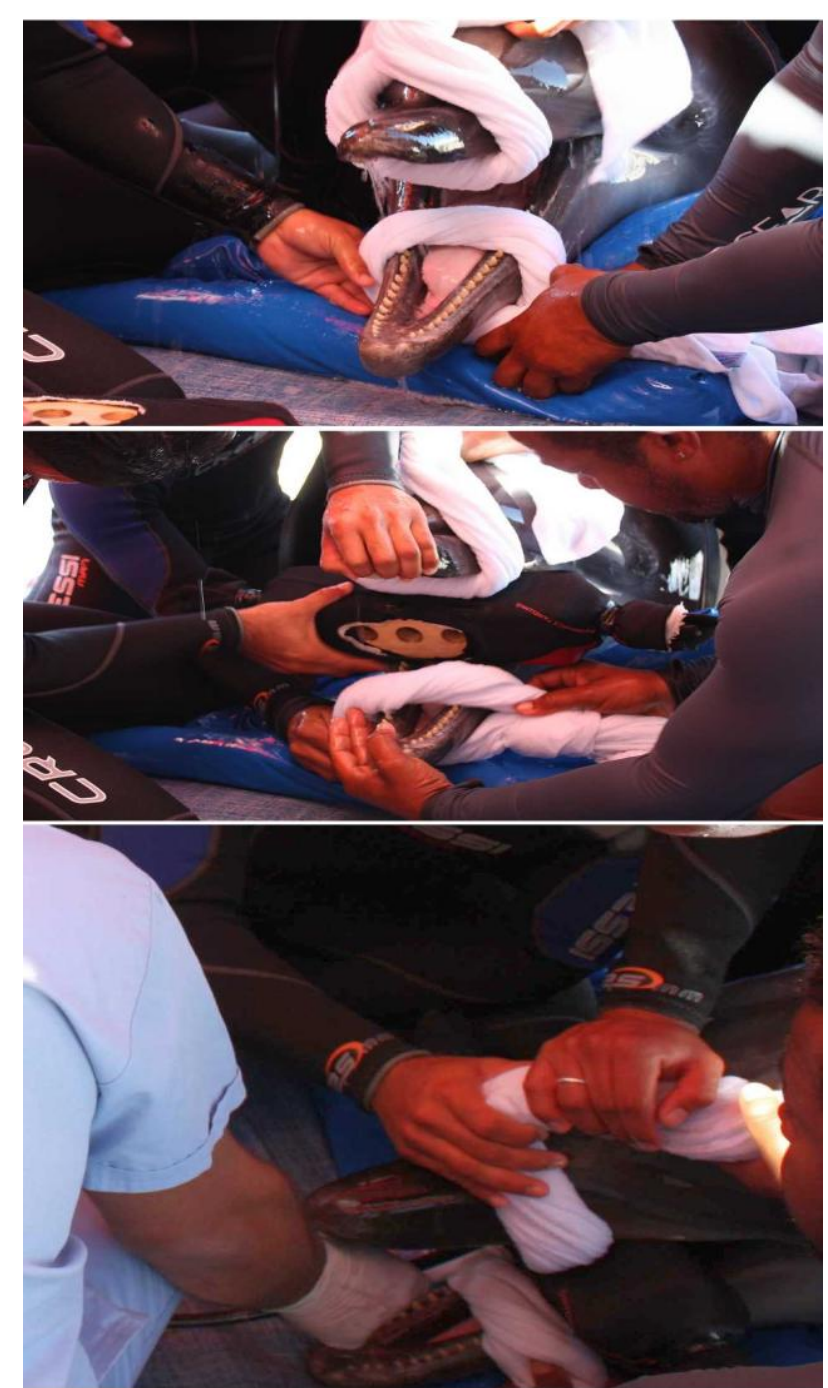

Figure 1:Gastroscopic procedure.Placing the endoscope.

Şekil 1: Gastroskopik prosedür.Endoskopun yerleştirilmesi

\section{Methods and Diagnosis}

Gastroscopy procedure was performed for diagnostic purpose. For that, starvation of the patient starting at least 6 hours before the procedure was requested. Because of the large size of our patient, we preferred a colonoscope (Pentax FC-38LW) with a $12.8 \mathrm{~mm}$ diameter and with a $170 \mathrm{~cm}$ working channel for detecting the foreign body and performing the removal procedure afterwards. Although there were no previous reports about the application without anesthesia, in this case no sedatives or anesthetics was applied to the patient who was indicated as calm tempered by its handlers and was reported to not have a good tolerance against parenteral drug applications. The patient tolerated the gastroscopic procedure very well. The dolphin was laid over a soft foam pillow during the procedure. It was kept in the sternal 
recumbency position during the application. The rostrum was stabilized by wrapping two bath sheets around the maxilla and mandible. In order to ensure the safety of the endoscopy and to prevent the animal from shutting its mouth during the procedure, a mouthpiece made of wood and covered with diving suit material with a $2 \mathrm{~cm}$ diameter hole in it to facilitate the passage of endoscope was placed into the rostrum (Figure 1).

The distal end of the endoscope was placed into the forestomach through the oropharynx and esophagus by applying a constant pressure. The swallowed foreign body was detected at approximately $120 \mathrm{~cm}$. The whole application and the image capturing were performed within the scope of standard gastroscopy procedure (including air insufflation, rotation, withdrawal, etc.). For the removal of the foreign body, reusable V-shaped grasping forceps were used.

Gastroscopy application of the outside of the water was performed consecutively twice for about 45 minutes. Following the first attempt, the dolphin was put into the pool and was commanded to move actively for 5 minutes following an hour of rest period in order to attempt to change the forward-facing position of the diving mask. Then the application was repeated by taking it to the pool side again. It was found that the position of the foreign body remained unchanged following the second attempt.

Since no anesthetic procedures were applied in either of the applications, the frequency and the force of the stomach peristalsis decreased sufficiently enough to permit gastroscopy for only after 20 minutes.

During the application, no lesions due to the foreign body were observed in the forestomach. The dolphin was kept in the shade during the application and its skin wetted.

\section{RESULTS AND DISCUSSION}

In this case it was learned from the history, the dolphin was likely swallowed a diving mask for a long time ago, and no clinical findings were identified. Thus, it is very difficult to recognize the swallowing of a foreign body in marine mammals if there is no history.

The diagnosis is usually established by observing the animal swallowing the object because the swallowed objects generally do not lead to any clinical findings. It is reported that loss of appetite, regurgitation or lethargy are rarely observed (Stoskopf 1998).
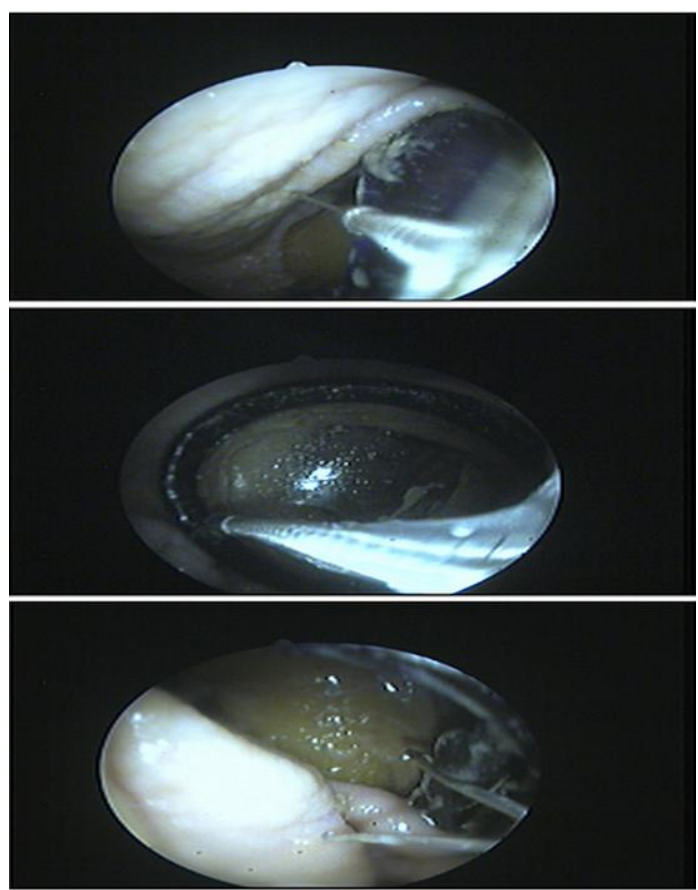

Figure 2: Removal procedure. The diving mask in the distal forestomach.

Şekil 2: Uzaklaştırma prosedürü.Distal ön miydede dalış maskesi.

In the presented case, it was stated that our patient had swallowed a foreign body (tip of a brush) before as well and then removed it by itself in time by vomiting. Animals generally remove the foreign bodies they swallow themselves by vomiting (Stoskopf 1998). However, Greenwood et al (1978) reported that these animals can only remove small foreign bodies by vomiting. Currently, the best method to use for diagnosis and removal is gastroscopy (Kyung-Yeon et al 2013, Stoskopf 1998). Nonetheless, the diagnosis of swallowed gastric foreign bodies in marine mammals can be established using ultrasonography (Stoskopf 1998) and radiography (Kyung-Yeon et al 2013) as well. It must be emphasized that, if there is a foreign body in marine mammals, removal is recommended. Because, in the family of marine mammals, which includes dolphins, the orificium, which opens to the second compartment of the stomach from the forestomach, is markedly narrow. Therefore, foreign bodies usually remain in the first compartment (Stoskopf 1998). In addition, it is reported that foreign bodies that remain in the forestomach for a long time will eventually cause gastric irritation and obstruction (Beroza et al 1981).

When a database search regarding the topic was performed, it was seen that different methods for the removal of foreign bodies in dolphins 
have been used. Beroza et al (1981) described a manual removal method for bottlenose dolphins. Nevertheless, the use of bare arm for removal is not a recommended application in today's conditions (Dover and Bonn 2001). However, in our opinion, if the foreign body is too large to remove, an attempt can be made to enter through the rostrum of the dolphin, which is laid on a ramp that slopes down forwards, with bare arms and to grab and remove the foreign body in the forestomach. In the presented case, the keeper Vet of the dolphinarium performed a similar application before the endoscopic procedure but could not reach the foreign body due to the large body of the dolphin. The method as defined above can be beneficial in dolphins with suitable size. On the other hand, Levy et al (2009), made use of a laryngeal snare in the removal of a fishnet swallowed by a bottlenose dolphin. Greenwood et al (1978), reported that removal of foreign bodies in dolphins can be performed by using various grasping forceps pushed forward down the work channel via use of a fiberscope. Applications that are performed without observation (hooked catheter, etc.) are likely to fail. For a successful removal, it is important to observe the swallowed object and to visually confirm its position. For this reason, gastroscopy is the most feasible method for diagnosis and removal. Taking the massiveness of the dolphin into account, an endoscope with a work channel with a suitable length should be preferred. Otherwise, as Sweeney and Radgway (1975) reported, forestomach monitoring will be limited. In most bottlenose dolphins, the forestomach can be easily monitored using an endoscope with a work channel of 100-140 cm (Greenwood et al 1978). However, it should be noted that most of the grasping forceps on the market are designed to remove smaller objects (Kyung-Yeon et al 2013). These forceps are inefficient for the removal of larger objects. Nonetheless, larger foreign bodies with a surface structure that can be tightly grasped or with a piece that can be held on to can be removed using these forceps. In the presented case, the diving mask which is a heavy material was firmly settled in the distal of the forestomach with its glass facing forward (Figure 2). It was found that its plastic surfaces that might have been grasped (edges, head band etc.) had become slippery since the mask was inside for a long time. The flexible plastic structures also hardened due to interaction with stomach fluids. Although the diving mask was repeatedly grasped by its suitable parts and pulled with a constant force using steel V-shaped grasping forceps, it disengaged from the forceps and the removal was unsuccessful. Another reason why we have failed, because of the endoscopic grasping forceps are sold for veterinary field is suitable for removal of smaller objects.

In the performed literature search (Web of Sci.) the number of reported gastric foreign body cases in dolphins was found to be limited. The presented case was reported in order to guide clinicians that are involved in endoscopic procedures in marine mammals. Currently the best method to use in the diagnosis and removal of swallowed foreign bodies in dolphins is gastroscopy.

\section{REFERENCES}

Kyung-Yeon E, Yong-Gu Y, Oh-Deog K. Modified endoscopic removal of foreign objects from the forestomach of a common bottlenose dolphin (Tursiops Truncatus). Pak Vet J. 2013; 33(2):251253.

Stoskopf MK. Marine Mammals. Environmental Diseases. Ed; Aiello SE, In: The Merck Veterinary Manual. 8th ed. Philadelphia, National Publishing Inc; 1998; pp. 1359.

Greenwood AG, Taylor DC, Wild D. Fiberoptic gastroscopy in dolphins. Vet Rec. 1978; 102:495-497.

Beroza GA, Barclay WP, McDonald SE, Ott JE. Manula retrievel of a gastric foreign body in an Atlantic bottlenose dolphin. J Am Vet Med Assoc. 1981; 179:12861288.

Dover SR, Bonn WN. Flexible and rigid endoscopy in marine mammals. Ed; Dierauf LA and Gulland FMD, In: CRC Handbook of Marine Mammal Medicine. 2nd ed. New York, CRC Press; 2001; pp. 621-635.

Levy AM, Brenner O, Scheinin A, Morick D, Ratner E, Goffman O, Kerem D. Laryngeal snaring by ingested fishing net in a common bottlenose dolphin (Tursiops Truncatus) off the Israeli shoreline. J Wildlife Dis. 2009; 45:834838.

Sweeney JC, Ridgway SH. Procedures for the clinical management of small cetaceans. J Am Vet. Med Assoc. 1975; 167:540-54 